\title{
Professional Fulfillment: Concept and Instrument Proposition
}

\author{
Ligia Carolina Oliveira-Silva' \\ Juliana Barreiros Porto ${ }^{2}$ \\ John Arnold \\ ${ }^{1}$ Universidade Federal de Uberlândia, Uberlância, $M G$ \\ ${ }^{2}$ Universidade de Brasilia, Brasilia, DF \\ ${ }^{3}$ Loughborough University, Leicester, UK
}

\begin{abstract}
This paper aims to propose a concept and an instrument of professional fulfillment (PF), which is theoretically defined as the perception of having attained or being on the right track for attaining one's most important career goals. The Professional Fulfillment Scale (PFS) was developed in order to operationalize PF, being tested across two studies. Regarding Study 1, in which 406 workers took part, results from exploratory factor analysis evidenced construct validity for PFS. In Study 2, in which 270 workers took part, results from confirmatory factor analysis and structural equation modeling presented satisfactory model fit indices for PFS. We conclude that both the professional fulfillment concept and the scale are useful for mapping people's importance and achievement of career goals and evaluation of progress, working as a diagnostic tool for career management. Keywords: professional fulfillment; career; goals
\end{abstract}

\section{Realização Profissional: Proposição de Conceito e Instrumento}

\begin{abstract}
Resumo
O presente artigo visa propor um conceito e um instrumento de realização profissional (RP), definida teoricamente como a percepção de se ter alcançado as metas de carreira mais importantes ou a avaliação positiva de que se está no caminho para alcançar tais metas. A Escala de Realização Profissional (PFS) foi desenvolvida para operacionalizar a RP, sendo sua estrutura testada em dois estudos. No Estudo 1, no qual participaram 406 trabalhadores, resultados da análise fatorial exploratória evidenciaram a validade de construto da PFS. No Estudo 2, no qual participaram 270 trabalhadores, os resultados oriundos da análise fatorial confirmatória e da modelagem por equações estruturais indicaram que a PFS apresenta índices de ajuste do modelo satisfatórios. Conclui-se que tanto o conceito de realização profissional quanto a PFS são úteis para mapear o grau de importância, alcance e progresso das metas de carreira, funcionando como ferramenta de diagnóstico para o gerenciamento de carreira.

Palavras-chave: realização profissional, carreira, metas
\end{abstract}

\section{Realización Profesional: Propuesta de Concepto y Instrumento}

\section{Resumen}

El presente artículo tiene como objetivo proponer un concepto y un instrumento de realización profesional (RP), la cual se define teóricamente como la percepción de haber alcanzado las metas más importantes de la carrera o la evaluación positiva de que se está en camino de lograrlas. La Escala de Realización Profesional (ERP) fue desarrollada para operacionalizar la RP, siendo su estructura puesta a prueba en dos estudios. En el estudio 1, en el cual participaron 406 trabajadores, los resultados del análisis factorial exploratorio mostraron validez de constructo de la ERP. En el estudio 2, en el que participaron 270 trabajadores, los resultados provenientes del análisis factorial confirmatorio y del modelado por ecuaciones estructurales, indicaron que la ERP presenta índices de ajuste de modelo, satifactorios. Como conclusión podemos decir que tanto el concepto como el instrumento de la ERP, son útiles para asignar el grado de importancia, alcance y progreso de las metas de la carrera, funcionando como una herramienta de diagnóstico para la gestión de la misma.

Palabras-clave: realización profesional; carrera; metas

How to achieve professional fulfillment? This is a question many people ask, though they rarely get satisfactory or conclusive answers. The perception of being professionally fulfilled certainly involves factors related to management and career development; however, the process of seeking professional fulfillment can be understood as essentially related to meeting the main work needs of people. Today, people have become entrepreneurs of their own careers, choosing jobs and activities that fit their personal goals and values, according to the protean career approach (Hall, 1996). Therefore, they are increasingly responsible for their own professional success, either by negotiating employment conditions and development opportunities within an organization, or by removing lasting bonds with organizations in general, such as in the boundaryless career approach (Arthur \& Rousseau, 1996). 
Another important issue concerns how people organize themselves to achieve their career goals. Career management involves identifying one or more career goals, combined with engaging in strategies that increase the likelihood that these goals will be achieved (Noe, 2013). As people differ in relation to the goals they prioritize in their careers and in the strategies they use to achieve them, we question how it would be possible to affirm that one has achieved professional fulfillment.

Considering that currently there are no definitions, concepts, models or instruments about professional fulfillment in the national or international literature, and given the recurrence of such terms both in world of work in general and in the career field, this article intends to fill this gap. Therefore, the present article aims at proposing a concept and an instrument of professional fulfillment, presenting it as a construct from the career field and operating it as a goal-based measure. Two studies were carried out to analyze the pertinence of the concept and the validity of the measurement instrument. Next, we will present the concept of professional fulfillment and the aspects that contextualize its relevance and elaboration.

\section{What is professional fulfillment?}

A very common problem faced by career counselors is that people rarely care about how little time they devote to reflecting and deciding about what they want to achieve in their careers. This is worrying, since careers are not merely sequences of random events occurring in people's lives, but rather a set of events induced and managed through mature and grounded decisions (Inkson, Dries \& Arnold, 2014). There is evidence, for example, that when people set career goals, as well as plans and strategies to achieve these goals, there is increased satisfaction both in the career and in financial gain (Abele \& Wiese, 2008).

Despite the lack of planning, people in general want to succeed in their careers, which is related to achieving goals. According to Fryer, Ginns and Walker (2014), the role of goal setting has never been as intensively researched as it is today. Including different contexts, such as the workplace (e.g., Locke \& Latham, 2002), sports (e.g., Smith, Ntoumanis, Duda, \& Vansteenkiste, 2011), eating disorders (e.g. Verstuyf, Patrick, Vansteenkiste, \& Teixeira, 2012) and education (e.g., Huang, Zhang, \& Broniarczyk, 2012), the importance of goals is clear, which reinforces the suitability of the proposition of professional fulfillment as a concept based on goals. Regarding career goals, evidence suggests that the quality of a person's career depends on how far the achievement of career goals is compatible with the preferred work context, as well as how these goals can actually be achieved (Greenhaus, Callanan \& Godshalk, 2010).

In addition, Heslin (2005) proposes that research in the career field should use theories that explore what matters most to people, as well as investigate how they perceive or anticipate success in their career. Therefore, professional fulfillment focuses on career goals; however, we should remember that professional fulfillment is not something static, but dynamic, derived from subjective assessment of the career, and can be altered depending on life events. In addition, achieving certain career goals may require more time for experience and maturity, so people can reach professional fulfillment not only by achieving all their goals, but also by assessing that they are on the right path to achieve them, that is, doing something that contributes to this. Therefore, we emphasize that professional fulfillment is not only about ends, but also about means.

As a concept from the career field, the proposition of professional fulfillment seeks to draw attention to the need to go beyond the organizational context and formal jobs, as suggested by the protean and boundaryless career approaches (Arthur \& Rousseau, 1996). The definition of professional fulfillment proposes that career goals may involve any type of expected outcome, provided that it is of outstanding importance to the individual.

In this sense, professional fulfillment can be defined as the perception of having reached one's most important career goals, or the positive evaluation of being on the right path to achieving these goals, which leads to the following questions: 1) What are career goals composed of? 2) How do people assess whether they are on "the right path"? Aiming to answer these questions, we should consider that career goals have their origin in personal values, and that the "right track" refers to the subjective validity that people make of their progress in their career. The definition of professional fulfillment is, therefore, composed of two dimensions: 1) Importance and fulfillment of career goals (content of goals) and 2) Evaluation of progress towards goals. In general, the proposed concept suggests that any work activity (including unpaid work), employment or occupation may present the potential of generating satisfaction, as long as it is possible for the individuals to realize that: 1) the most important career goals 
are being achieved; 2) there is progress towards them. Next, we will present and discuss the theoretical bases that directly substantiate the concept of professional fulfillment proposed here.

\section{Theoretical fundamentals of professional fulfillment}

According to goal theory, personal goals can be understood from the content and process perspectives (Austin \& Vancouver, 1996; Elliot \& Fryer, 2008; Gollwitzer \& Moskowitz, 1996). The content perspective describes the orientations that people have about their future, revealing their desires, worries and intentions. The first of the constitutive dimensions of professional fulfillment refers to the importance and achievement of specific contents of career goals. Similarly, studies such as those conducted by Nurmi, Salmela-Aro and Koivisto (2002) investigate the impact of assessing the importance and achievement of work-related goals on the success of young adults in finding a job after graduation. Studies such as those conducted by Little and Gee (2007), Wiese and Salmela-Aro (2008), and Hyvonen et al. (2009) describe the content of sets of personal goals at work; however, such studies are not successful in proposing unified models of possible contents of career goals, reducing the reliability of these studies and the possibility of replication.

In this sense, the concept presented for professional fulfillment aims to reduce this gap, since it considers the content of career goals, at its base, as composed of personal values, whose theories have presented increasing robustness. According to Schwartz (1992; Schwartz et al., 2012), values are criteria or goals that transcend specific situations, ordered by their importance and that serve as principles that guide the lives of individuals. The content of values is essentially motivational, representing abstract goals that apply in diverse contexts and times, and is based on universal human needs.

After evaluating the values of 9,140 people across 20 countries, Schwartz (1992) obtained a dimensional structure of 10 values: self-determination, stimulation, hedonism, achievement, power, safety, conformity, tradition, benevolence and universalism. These values can be grouped into two bipolar dimensions: Self-enhancement versus Self-transcendence and Openness to change versus Conservation. Self-transcendence encompasses the values of universalism and benevolence, emphasizing equality and concern for the well-being of others. Contrarily, Self-enhancement includes the values of power and achievement, regarding the pursuit of success and dominance of others. Openness to change encompasses the values of hedonism, stimulation and self-determination, referring to the desire for new experiences and the quest for independence of thought and action. On the other hand, Conservation involves the values of tradition, conformity and security, which stand for protection and stability, valuing the maintenance of traditions and the status quo.

Schwartz's human values model has been widely accepted over the years and around the world. Its second-order bipolar dimensions were found and replicated by several studies (see Elster \& Sagiv, 2015). In this sense, goals are understood in terms of values (Schwartz et al., 2012), which make them broader and more abstract than they usually are according to goal theories. Greenhaus et al. (2010) even suggests Schwartz's theory to understand what people look for in their careers, arguing that understanding the value structure proposed by Schwartz contributes to important insights about people's career aspirations. For example, a person who prioritizes material and political values has little chance of being happy in a low-paid occupation with few leadership opportunities. In general, the same occupation or job varies in relation to the ability to satisfy people's values, so that they tend to be more satisfied with jobs in which they can realize their priority values. In short, a goal represents the manifestation of the most important values of the individual (Greenhaus et al., 2010).

In relation to the achievement of goals that are important, some theories suggest that people benefit from achieving goals especially when they are consistent with inherent psychological needs (Sheldon \& Kasser, 1998). According to Sheldon and Elliot's Self-Concordance Model (1999), people who pursue self-concordant goals (with interests and values) work harder to achieve these goals, which increases the likelihood of effective attainment (Gaudreau, Carraro \& Miranda, 2012). Therefore, the proposed concept of professional achievement is in line with the literature, suggesting that individuals are more likely to feel professionally fulfilled when they reach their most important (self-concordant) career goals.

The second dimension proposed for the concept of professional achievement, called goal progress, refers to the individual's degree of satisfaction with his or her progress toward career goals. Carver and Scheier's Theory of Control (1982) supports this dimension, since it aims to explain the behaviors that permeate the process that goes from the establishment to the achievement of 
goals. The Control Theory proposes that goal setting is the result of the pursuit of a performance standard, i.e., monitoring the progress of goals involves periodic checking of the behaviors performed (e.g., how much was eaten) and/or the outcome (e.g., weight loss), comparing such perceptions with the desired performance pattern (e.g., losing 2kg) (Baumeister \& Vohs, 2007, Carver and Scheier 1982, Webb, Chang, \& Benn, 2013). Monitoring progress towards goals can help achieve these goals by helping to identify discrepancies between current and desired states, allowing people to recognize gaps and adjust behaviors to strive harder (Myrseth \& Fishbach, 2009).

Both dimensions proposed for professional fulfillment are important for understanding the concept, since not only the achievement or progress towards goals generates greater well-being, but also the types of goals sought and the motivation for the search (Linley et al., 2010). Achieving self-concordant goals, for example, contributes to greater well-being than achieving non-congruent goals (Sheldon \& Kasser, 1998). Evidence such as this emphasizes the importance of both content and progress of goals in defining professional fulfillment.

When presenting the concept of professional fulfillment, it is necessary to construct its measuring instrument, which must translate and operationalize its theoretical dimensions. Therefore, Study 1 proposes the Professional Fulfillment Scale (PFS), analyzing the construct validity and reliability by means of Exploratory Factor Analysis. Study 2, in turn, tests the PFS structure found in Study 1 by means of confirmatory factor analysis, and uses structural equation modeling to analyze how the two dimensions of the scale interact to generate the latent variable equivalent to professional fulfillment.

$\underline{\text { Study } 1}$

\section{Method}

\section{Scale Development Procedures}

At first, 20 semi-structured interviews were carried out to find out what people understood by professional fulfillment. The result of these interviews led to the conclusion that professional fulfillment presented distinct meanings to people (e.g., some attributed professional fulfillment to status, or stability, others considered it more important to do what they liked). Thus, it was identified that the human values theory by Schwartz et al. (2012) translated the content addressed by these people, since they attributed professional achievement to what they valued most in terms of career. The notion of process was also identified in the interviews, that is, some people considered themselves to be professionally fulfilled even though they had not yet fully attained what they wanted most in their careers, but they understood that they were taking a path that would contribute to that.

Therefore, to grasp both dimensions of the concept of professional fulfillment, the Professional Fulfillment Scale (PFS) was developed to present two distinct parts, related to assessing the content and progress of goals. In the content part, the second-order dimensions proposed by Schwartz (self-transcendence, self-enhancement, openness to change and conservation) were considered theoretical umbrellas, as proposed by the author in his theory; however, the first version of the PFS contemplated the 19 first-order factors of the model by Schwartz et al. (2012). In order to construct the items, both the personal values questionnaire PVQ5X (Schwartz et al., 2012, 57 items) and the Work Values Scale (EVT-R - Porto \& Pilati, 2010, 38 items) were considered, and the writing of the sentences was adapted to the format of career goals. At least three items were suggested for each of the 19 factors, so some factors presented more than three items. Therefore, the first version of the content part of the PFS originally presented 69 items. The item-factor relation followed the premises of Schwartz et al. (2012) and Porto \& Pilati (2010), but we also used analysis with two judges, who knew the theories used, in order to corroborate the recommended relations. For each item, two answers were requested: one about subjective importance (as something I value in my career, this goal is: $0=$ not important to $4=$ extremely important), and another about the degree of achievement (the achievement of this goal at the current moment of my career is: $0=$ none to $4=$ total).

However, in order to analyze the relation between importance and achievement and to obtain the resulting score, the following formula must be used: PFDI = $\mathrm{i}(\mathrm{a}-1)$, in which PFDI = professional fulfillment degree indicator; $\mathrm{i}=$ importance; $\mathrm{a}=$ achievement. Only values equal to zero or above should be considered. This calculation allows us to analyze how people achieve the career goals they value most, which is one of the defining dimensions of professional fulfillment and, therefore, one of its indicators. The minimum PFDI score will be 0 (obtained with any value of importance 
and zero achievement), being the most critical situation in relation to professional fulfillment, while the maximum score will be 12 (maximum importance and achievement), that is, the higher the PFDI score, the more people reach their priority goals, which would indicate greater professional fulfillment. Such a score also reflects that an unimportant goal that is less achieved is less unfavorable than when an important goal has no achievement at all. Likewise, it would be better to achieve a low-value goal than not achieving any goal at all. This type of formula has been commonly used in the literature as a strategy to calculate competence gaps, as proposed by Brandão et al. (2012), as well as to analyze the gap between preferred and received leadership (Lambert et al., 2012).

Regarding the dimension goal progress, we present questions that aim to assess people's current career status, analyzing their progress towards career goals, and how satisfied they are with such progress. Table 1 presents the questions and respective forms of response of this dimension.

PFS goal progress part represents the second indicator of professional fulfillment, since even if the individual has not fully attained his or her most important career goals, the evaluation that they are progressing toward them may indicate professional fulfillment. This means that when people realize that they are where they should be or where they could be in their careers, even if this stage does not represent the full achievement of their goals, professional fulfillment can be experienced to some extent, therefore the concept does not represent something static, but a dynamic and subjective process. Although the development of objective measures of goal progress is challenged by the uniqueness of the set of goals pursued by each individual, the goal-pursuit process has previously been operationalized as perceived progress. Previous studies (Monzani, et al., 2015) show that it is possible to assess progress in the format of people's subjective assessment of improvement towards personal goals, which is compatible with the operationalization of goal progress proposed by the PFS.

The PFS framework addresses the two most commonly used measures in targeting, which are goals lists and the idiographic approach (Klug \& Maier, 2015). In the first case, a list of predefined goals is provided and people are asked to indicate what goals they are currently pursuing, which is equivalent to part of the goal content of the PFS. In contrast, the idiographic approach requires people to manage personal goals they are striving for, which are met by the open question (see Table 1) required in the goal progress part of the PFS.

\section{Participants}

A total of 406 workers with various occupations participated in the study, among whom $62.1 \%$ were women, $58.1 \%$ were single, $62.6 \%$ were undergraduate or graduate students $(37.4 \%)$ and $45 \%$ were younger than 25 years old. However, there were participants of various age groups (26 to 35 years

Table 1.

Questions about goal progress in the PFS

\begin{tabular}{|c|c|c|c|c|c|}
\hline Question/Item & & Tyt & ef respons & & \\
\hline $\begin{array}{l}\text { 1. Think again about your career. Describe } \\
\text { the main goal you set for yourself as a } \\
\text { professional, using a maximum of } 5 \text { words: }\end{array}$ & & & Open & & \\
\hline 2. If you answered NO in the previous & 1 & 2 & 3 & 4 & 5 \\
\hline $\begin{array}{l}\text { question, on a scale from } 1 \text { to } 5 \text {, evaluate } \\
\text { how close you are to achieving this goal: }\end{array}$ & $\begin{array}{l}\text { Nothing } \\
\text { Close }\end{array}$ & Little Close & Halfway & Very Close & $\begin{array}{l}\text { Reached } \\
\text { the goal }\end{array}$ \\
\hline 3. How much do you think your current job & 1 & 2 & 3 & 4 & 5 \\
\hline helps you achieve this goal? & Nothing & Little & Indifferent & Very & Totally \\
\hline 4. How satisfied are you with your progress & 1 & 2 & 3 & 4 & 5 \\
\hline in relation to your career goal? & Nothing & Little & Indifferent & Very & Totally \\
\hline 5. How professionally fulfilled do you & 1 & 2 & 3 & 4 & 5 \\
\hline currently consider yourself? & Nothing & Little & Indifferent & Very & Totally \\
\hline
\end{tabular}


$=30.1 \%$, 36 to 55 years $=14.9 \%, 46$ to 55 years $=$ $7.5 \%$, more than 55 years $=1.2 \%$ ).

\section{Procedures}

Participants were recruited at undergraduate and postgraduate institutions. All participants were informed about their rights as volunteers by reading the ICF (Informed Consent Form), which was signed when they agreed to participate in the research. The questionnaire was answered in classrooms, after academic activities, with the consent of the competent authorities.

\section{Data analysis}

After analyzing and observing the statistical principles, an Exploratory Factor Analysis (EFA) was performed. First, we conducted the main component analysis, evidencing the factorability of the instrument. Next, we performed principal axis factoring using Promax rotation. In the goal content part, the scales of importance, achievement and the PFDI score were analyzed separately, so that the items that met the inclusion criteria for the two scales and the PFDI (described below) were maintained. The items of the goal progress dimension were analyzed together, except for question 1, which is open and aimed only to activate a goal to guide the other issues. Analyzes were performed using the SPSS (Statistical Package for Social Science), version 20.0.

\section{Results}

Results of the exploratory factor analysis evidenced the presence of four factors for the goal content part, according to Table 2. These four factors represent the types of career goals, being compatible with Schwartz et al.'s (2012) two second-order bipolar dimensions, as presented in Table 3, which also includes the descriptive statistics for each scale and the PFDI score.

The solution obtained by means of exploratory factor analysis for the goal content part presents only 22 items; 47 items were excluded due to the following criteria: correlations of the anti-image matrix (results below .30 were excluded); factorial load of items (items with load below .40 were excluded); theoretical compatibility of the item with the factor; meeting previous criteria for the scales of importance, achievement, and PFDI score simultaneously. The reliability indices obtained are satisfactory (between .84 and .92) and the correlations between the four factors vary between 28 and .45 for the importance scale $(p<.001)$, between
.40 and $.60(\mathrm{p}<.001)$ for the achievement scale, and between .50 and $.66(p<.001)$ for the PFDI score. The four factors together explain $51.4 \%$ of the variance considering the importance scale, $58.2 \%$ considering the achievement scale and 58.5\% considering the PFDI score. Regarding the goal progress part, it was identified as unifatorial ( $49.5 \%$ of variance explained), with a reliability index of .78 and factorial load of items varying between .62 and .73 .

Considering the results obtained in Study 1, we deemed it necessary to perform a second study, with a new data collection, the purpose of which would be to test the factorial structure found with the confirmatory factor analysis. We also aimed to analyze, via structural equation modeling, if the theoretical dimensions proposed for professional fulfillment would be able to generate, empirically, the latent variable equivalent to the construct.

Study 2

\section{Method}

\section{Participants}

The study included 270 workers, mostly women (76.2\%), under $30(\mathrm{M}=27.9$ years), single $(59.5 \%)$, students $(86 \%)$, working for less than 2 years $(29.7 \%)$ or between 2 and 5 years $(29.3 \%)$.

\section{Instrument and Procedure}

The set of items obtained in Study 1 represented the version of the PFS used in Study 2, so that in the goal content part, participants assessed the degree of importance and achievement of 22 items, while in the goal progress part, the same 5 questions from the original scale were used, since the 4-Likert-like response questions included in the EFA were maintained, as was the open question. Participants were recruited using convenience and snowball sampling, being invited via e-mail to participate in an online survey. The same ethical procedures followed on Study 1 were respected, but with a different approach - before starting the survey, people read the ICF and agreed to participate by clicking on "proceed".

\section{Data analysis}

Confirmatory Factor Analysis (CFA) was performed to test the PFS factor structure obtained in Study 1, along with Structural Equation Modeling (SEM), which was used to analyze whether the content and 
Table 2.

Factorial solution for the goal content part of the PFS $(N=406)$

\begin{tabular}{|c|c|c|c|c|c|c|c|c|c|c|c|c|}
\hline & \multicolumn{4}{|c|}{ Importance } & \multicolumn{4}{|c|}{ Achievement } & \multicolumn{4}{|c|}{ PFDI } \\
\hline & 1 & 2 & 3 & 4 & 1 & 2 & 3 & 4 & 1 & 2 & 3 & 4 \\
\hline Cronbach's Alpha & 0.81 & 0.79 & 0.74 & 0.74 & 0.86 & 0.80 & 0.82 & 0.76 & 0.87 & 0.82 & 0.81 & 0.78 \\
\hline 10 Be treated with respect and dignity & .70 & & & & .88 & & & & .83 & & & \\
\hline 21 Felling good about the work I do & .66 & & & & .72 & & & & .74 & & & \\
\hline 13 Like what I do & .63 & & & & .63 & & & & .72 & & & \\
\hline 12 To be respected and recognized for my work & .58 & & & & .62 & & & & .47 & & & \\
\hline 22 Take pleasure in work & .48 & & & & .56 & & & & .81 & & & \\
\hline 14 Succeed at work & .48 & & & & .49 & & & & .53 & & & \\
\hline 11 Have a good personal image & .48 & & & & .48 & & & & .44 & & & \\
\hline 6 Compete to overcome challenges & & .73 & & & & .79 & & & & .63 & & \\
\hline 8 Perform challenging tasks & & .68 & & & & .68 & & & & .82 & & \\
\hline 7 Getting to know new places & & .68 & & & & .61 & & & & .62 & & \\
\hline 9 Have a job that brings constant novelty & & .62 & & & & .56 & & & & .57 & & \\
\hline 5 Have varied experiences & & .57 & & & & .56 & & & & .55 & & \\
\hline 1 Collaborating for the development of society & & & .70 & & & & .82 & & & & .73 & \\
\hline 3 Protect nature from threats & & & .61 & & & & .72 & & & & .85 & \\
\hline 2 Improve people’s lives & & & .61 & & & & .70 & & & & .66 & \\
\hline 4 Help the world to be a better place & & & .59 & & & & .62 & & & & .68 & \\
\hline 16 Meet society's expectations & & & & .69 & & & & .62 & & & & .55 \\
\hline 15 Have routines to do the job & & & & .67 & & & & .52 & & & & .47 \\
\hline 17 Avoid disappointing people & & & & .65 & & & & .49 & & & & .67 \\
\hline 19 Perform work that is compatible with the & & & & & & & & & & & & \\
\hline beliefs and values of the society in which I live & & & & .56 & & & & .47 & & & & .49 \\
\hline 18 Have a work environment with clear hierarchy & & & & .56 & & & & .46 & & & & .58 \\
\hline 20 Submit to the opinion of others & & & & .44 & & & & .44 & & & & .49 \\
\hline
\end{tabular}

goal progress parts would generate the latent variable equivalent to professional achievement. The estimation method used was maximum likelihood, since the normality assumptions of the distribution were met. Both CFA and SEM were performed by AMOS, SPSS 20.0 package, specific for such analyzes.

\section{Results}

First, the content part of the PFS was analyzed, which aimed to confirm the factorial structure obtained in Study 1. A priori, the results of the CFA indicated that the fit of the model could be improved. The observance of the fit coefficients, item loads in each factor and modification indices resulted in the exclusion of six items: $6,10,11,12,15$ and 20 (see Table 2). The main criteria for the exclusion of items were: a) factorial load (items with load below 0.50 in more than one scale - importance, achievement, and PFDI - were excluded); b) duplication of ideas in the wording of the item (e.g. "Be treated with respect and dignity"; "Be respected and recognized for my work"); c) theoretical association of the content of the item with the other items of the factor and with the definition of the factor itself (e.g. "having a good personal image" and "competing to overcome challenges" in the factor openness to change); d) model fit increase after the removal of the items. The removal of these 6 items culminated in the reduction of the scale from 22 to 16 items, with four items in each factor. When considering the model with 22 items, the fit indices were: $\chi^{2}=345.80, \chi^{2} / \mathrm{df}$ $=1.71, p=.000, \mathrm{CFI}=0.95$, TLI $=0.94$, RMSEA $=$ 
Table 3.

Factors and means of Study 1 for goal content of the PFS (N=406)

\begin{tabular}{|c|c|c|c|c|}
\hline Factor & Definition & Items & $\begin{array}{c}\text { Scale/ } \\
\text { score }\end{array}$ & Mean (SD) \\
\hline \multirow{3}{*}{$\begin{array}{l}\text { 1. Self- } \\
\text { enhancement career } \\
\text { goals }\end{array}$} & \multirow{3}{*}{$\begin{array}{l}\text { Pursuit of success, pleasure, respect and } \\
\text { acknowledgment in the career. }\end{array}$} & \multirow{3}{*}{$\begin{array}{l}10,11,12,13 \\
14,21,22\end{array}$} & I & $3.44(0.55)$ \\
\hline & & & A & $2.67(0.82)$ \\
\hline & & & PFDI & $5.89(3.20)$ \\
\hline \multirow{3}{*}{$\begin{array}{l}\text { 2. Openness to } \\
\text { change career goals }\end{array}$} & \multirow{3}{*}{$\begin{array}{l}\text { Pursuit of innovating and challenging } \\
\text { experiences in the career. }\end{array}$} & \multirow{3}{*}{$\begin{array}{l}5,6 \\
7,8,9\end{array}$} & I & $2.96(0.74)$ \\
\hline & & & A & $2.15(0.89)$ \\
\hline & & & PFDI & $3.72(3.09)$ \\
\hline \multirow{3}{*}{$\begin{array}{l}\text { 3. Self- } \\
\text { transcendence } \\
\text { career goals }\end{array}$} & \multirow{3}{*}{$\begin{array}{l}\text { Concern about nature and the well-being of } \\
\text { others in the career }\end{array}$} & \multirow[t]{3}{*}{$1,2,3,4$} & I & $3.04(0.74)$ \\
\hline & & & A & $2.23(0.92)$ \\
\hline & & & PFDI & $4.10(3.23)$ \\
\hline \multirow{3}{*}{$\begin{array}{l}\text { 4. Conservation } \\
\text { career goals }\end{array}$} & \multirow{3}{*}{$\begin{array}{l}\text { Concern about meeting the demands of } \\
\text { society, not disappointing people, and following } \\
\text { the rules and hierarchy in the career. }\end{array}$} & \multirow{3}{*}{$\begin{array}{c}15,16 \\
17,18,19,20\end{array}$} & I & $2.64(0.77)$ \\
\hline & & & A & $2.31(0.75)$ \\
\hline & & & PFDI & $3.77(2.72)$ \\
\hline
\end{tabular}

Note. $\mathrm{I}=$ Importance; $\mathrm{A}=$ Achievement; PFDI = Professional Fulfillment Degree Indicator; $\mathrm{SD}=$ Standard deviation.

0.05, SRMR $=0.04$. Comparatively, the fit indices of the 16-item model were: $\chi^{2}=148.83, \chi^{2} / \mathrm{df}=1.55, p=$ .000, CFI $=0.98$, TLI $=0.97$, RMSEA $=0.04$, SRMR $=0.03$, which evidences considerable improvement in the indices compared to the 22-item model.

The results above relate to the calculation of fit indices when considering the answers obtained with the PFDI score. The fit indices of the 16-item model were also calculated separately for such scales, and the values found were close to those previously mentioned (Importance: $\chi^{2}=149.86, \chi^{2} / \mathrm{df}=1.59, p=.000$, CFI $=0.95$, TLI $=0.94$, RMSEA $=0.04$, SRMR $=0.05$; Achievement: $\chi^{2}=152.53, \chi^{2} / \mathrm{df}=1.59, p=.000$, CFI $=0.97$, TLI $=0.97$, RMSEA $=0.04$, SRMR $=0.03$ ), but slightly lower, which supports the relevance of the IDPF score. After the items were excluded, the reliability coefficients were recalculated for each factor, as shown in Table 4. It is possible to observe that the achievement scale had better coefficients than the importance scale, which can be explained by the fact that the achievement of career goals would be more concretely assessed than importance.

The dimension of goal progress of the PFS was also analyzed by the CFA, whose results indicated that the structure obtained in Study 1 is consistent. The model fit indices for this dimension were: $\chi^{2}=2.602, \mathrm{p}$ $=.272, \chi^{2} / \mathrm{df}=1.30, \mathrm{RMSEA}=0.03, \mathrm{CFI}=0.99$, TLI $=0.99$, SRMR $=0.01$, which shows an excellent fit. As shown in Table 3, the alpha for this dimension of the scale was .78 .

Finally, it was verified whether the dimensions goal content and progress of the PFS could generate the latent variable equivalent to the professional achievement, which would corroborate empirically the existence of the model. For the specified model, the fit indices obtained were: $\chi^{2}=42.72, \mathrm{p}=.001, \chi^{2} / \mathrm{df}=$ 2.24, $\mathrm{RMSEA}=0.06, \mathrm{CFI}=0.98, \mathrm{TLI}=0.97, \mathrm{SRMR}=$ 0.03 . Such results show a good fit of the model, indicating that the goal content part, composed of 4 factors, together with the goal progress part, generate a latent factor equivalent to professional fulfillment. Therefore, it is possible to consider that the PFS represents, in a measurable way, the construct of professional fulfillment, according to the model and factorial loads presented in Figure 1. An alternative model was also analyzed when calculating the factors of the content dimension, making them observable variables, with fit indices rather high: $\chi^{2}=23.59, \mathrm{p}=.212, \chi^{2} / \mathrm{df}=1.24$, RMSEA $=0.03, \mathrm{CFI}=0.99, \mathrm{TLI}=0.99, \mathrm{SRMR}=0.02$.

\section{Discussion}

The construction of a valid and reliable instrument is as important as the proposal of an innovative construct, such as the case of professional fulfillment. The concept of professional fulfillment is pertinent 
Table 4.

Cronbach's alphas after the CFA

\begin{tabular}{lccccc}
\hline & Complete scale & Self-enhancement & Openness to change & Self-transcendence & Conservation \\
\hline Importance & .82 & .76 & .72 & .74 & .74 \\
Achievement & .93 & .91 & .84 & .86 & .79 \\
PFDI & .92 & .89 & .82 & .85 & .78 \\
Progress of goals & .78 & - & - & - & - \\
\hline
\end{tabular}

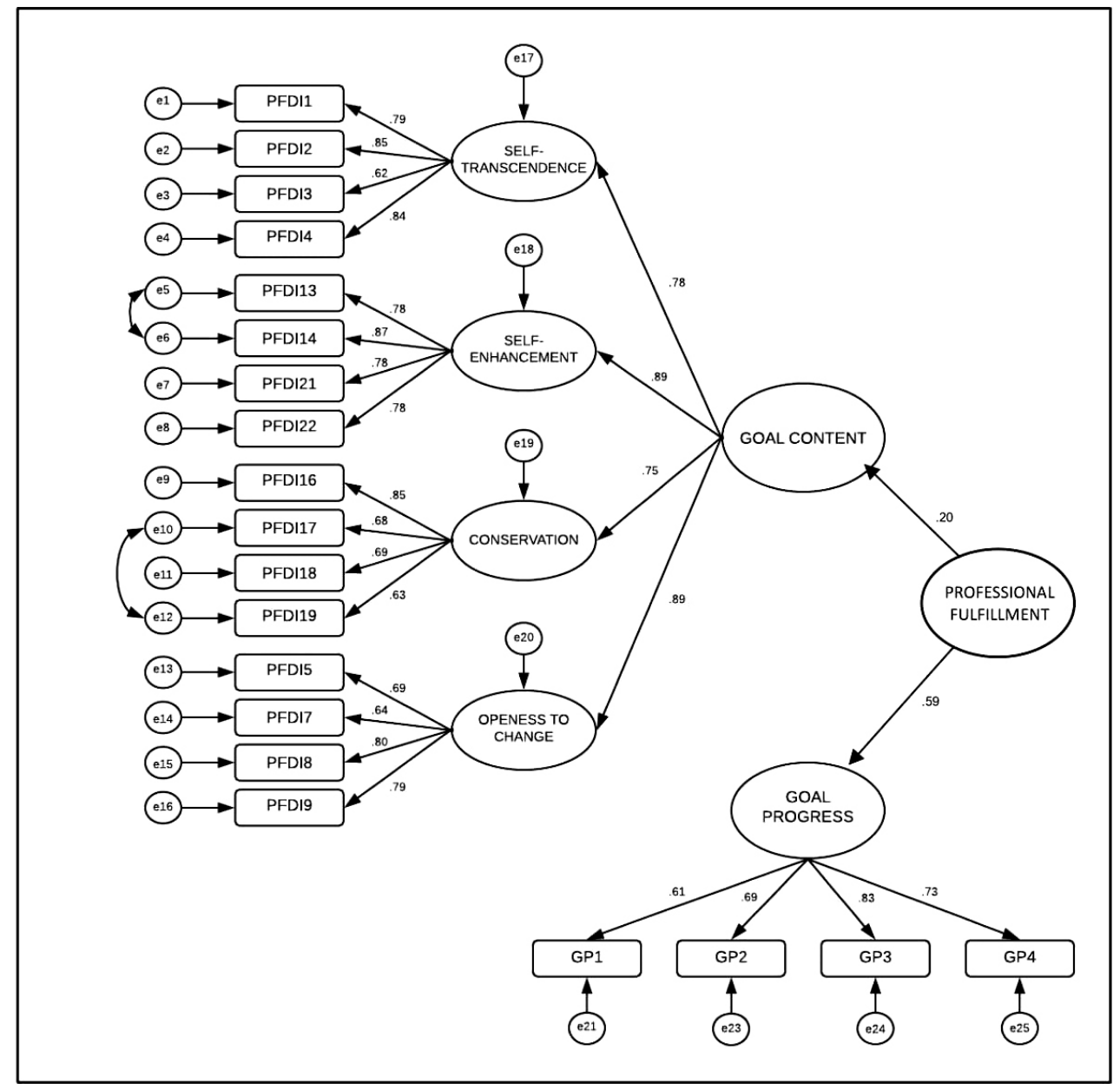

Figure 1. Model of structural equation of professional fulfillment

because it aligns with contemporary career premises (e.g., Hall, 1996; Arthur \& Rousseau, 1996), whereby people become increasingly responsible for their professional choices and, consequently, for their realization. Another important point relates to the focus on goal theories, meeting the need for more research to indicate how goals can lead people to action to improve their work lives (Greenhaus, Callanan \& Godshalk, 2010; Heslin, 2005). The proposed concept also makes an important contribution by suggesting goal content based on a solid theory of values (Schwartz et al, 2012), which increases the power of generalization and replications, and contributes to solve the consensus problem between goal content theories. 
Regarding the PFS, it is possible to affirm that Study 1 presents plausible evidence of its adequacy, according to the results of the exploratory factor analysis. Regarding the construct validity, it is necessary to highlight the advances represented by the content part of the PFS, in which the PFDI score between importance and achievement is calculated. Such a score presents adequate reliability indices, being psychometrically valid to measure the gap. Moreover, it represents the gap between achieving or not what is really valued, which operationalizes one of the dimensions of the theoretical definition of professional fulfillment. This contributes to the understanding that not everything the individual achieves is relevant, because it is better when people achieve what matters most to them, rather than when they achieve something they do not value. The use of such a score also helps to reduce the impact of mere self-report, often criticized in the literature due to its high degree of susceptibility.

However, some observations are pertinent with respect to the construction of the PFS. In relation to the 19 factors advocated by Schwartz et al. (2012) and used as the basis for the first version of the PFS, it is observed that in the present study such a structure did not find empirical support as the author proposes it, with support only for second-order bipolar dimensions (self-transcendence, self-enhancement, openness to change and conservation), which led to a significant decrease of items. One possible reason for this is that the items initially advocated by Schwartz to represent general human values, were adapted to the context of career goals. This may have caused changes in meaning and, consequently, in the factorial structure, leading to the exclusion of items whose meaning has been affected. In addition, some items of the initial instrument had contents that were relatively distant from the career context (e.g., "recognize my insignificance in the face of the greatness of things", "to meet my family's needs"), which may have contributed to the low factor load and consequent removal of items.

Regarding the reduction of the scale from 22 items to 16, although the 22-item model presented acceptable fit indices, the most parsimonious model was chosen. In addition, it is observed that the increase in the values of CFI and TLI to more than 0.95 , as well as the reduction of RMSEA to below 0.05, represents the fulfillment of the criteria established by Kline (2010) so that the model fit is satisfactory and not only acceptable. Thus, the results obtained in Study 2 showed satisfactory fit indices for the factorial structure of the scale, as well as in relation to the convergence of the two parts in the formation of professional fulfillment as a latent variable. These results demonstrate the robustness of the professional fulfillment concept operationalization, as well as the pertinence of its constituent dimensions.

Overall, professional fulfillment represents a relevant career-building construct, since it takes individual parameters of excellence into account - people have distinct career aspirations, so they will be professionally fulfilled by achieving compatible career goals with such aspirations. Professional fulfillment can be linked to any type of goal, as long as it relates to the most important values and needs of the individual, as proposed by the content dimension of the concept and the instrument of professional fulfillment. Both the 10-value (Schwartz, 1992) and the 19-value (Schwartz et al., 2012) models present variations around the world. However, it is observed that the theoretical division between the four second-order factors remains in several studies (Elster \& Sagiv, 2015), and also in the present one. Therefore, it is possible to state that the goal content dimension of the PFS, in its final format, reflects the essential core of Schwartz's value theory, translated by the four factors that are equivalent to the second-order dimensions of human values theory.

It is emphasized that professional fulfillment may not be perceived only when people fully achieve their most important career goals; often the current stage of the career is the maximum one can attain at the moment, considering the range of factors that can intervene in a context. According to the concept of professional fulfillment, if individuals realize that they are progressing towards their goals, they could also perceive themselves as professionally fulfilled. Therefore, it is possible to affirm that the professional fulfillment concept and instrument meet the content and process perspectives advocated by goal theories (Austin \& Vancouver, 1996; Elliot \& Fryer, 2008; Gollwitzer \& Moskowitz, 1996). In short, professional fulfillment presupposes that career quality depends on how far the achievement of priority goals can realistically be achieved (Greenhaus et al., 2010).

\section{Final considerations}

The objective of this article was to propose a concept and instrument of professional fulfillment, presenting evidence that corroborates the validity and reliability of both the concept and the instrument. One of the practical implications of professional 
fulfillment concept and instrument involves their use for career guidance and counseling, as it facilitates the mapping of people's career goals, allowing more informed professional decision-making, as well as outlining strategies for reaching goals. An instrument that makes it possible to identify the most important career goals, the current degree of achievement and the progress towards such goals represents a broad diagnostic tool for the area of career development and management. Therefore, career counselors could make use of the PFS to help people increase their selfawareness and develop career projects based on their priority values, besides assessing how close they are to reaching their most important goals.

One of the limitations of this research is that, when comparing the two parts of the PFS, it is observed that the degree of development and the amount of information addressed by the goal content part is, to a certain extent, higher than that brought by the goal progress part, which indicates that the latter can be improved. Another indicative of this refinement is that evidence suggests that people tend to exaggerate their mental representations of levels of progress in order to convince themselves that they are more likely to achieve their goals than they really are (Huang et al., 2012).

Another limitation concerns the sample, which in both studies is relatively young and culturally homogeneous. Therefore, future research can be conducted to compare professional achievement among young people in different jobs, career stages and socio-economic contexts.

The absence of other types of validity also represents a factor to be chosen, since it would be pertinent to analyze how professional achievement can predict behaviors, emotions and cognitions. Longitudinal research designs would also be relevant to analyze how career achievement can undergo career changes.

Future studies on professional achievement should analyze its relationships with other career aspects, such as choice, planning, and development. Studies involving the possible backgrounds and consequences of professional fulfillment are also necessary, especially about which individual and contextual variables are associated with greater professional fulfillment.

\section{References}

Abele, A. E., \& Wiese, B. S. (2008). The nomological network of self-management strategies and career success. Journal of Oсcupational and Organizational Psychology, 81, 733-749. doi: 10.1348/096317907X256726

Arthur, M. B., \& Rousseau, D. M. (1996). The boundaryless career: A new employment principle for a new organizational era. New York: Oxford University Press.

Austin, J. T., \& Vancouver, J. B. (1996). Goal constructs in psychology: Structure, process, and content. Psychological Bulletin, 120, 338-375. doi:10.1037/0033-2909.120.3.338

Baumeister, R. F., \& Vohs, K. D. (2007). Self-regulation, ego-depletion, and motivation. Social and Personality Psychology Compass, 1(1), 115-128. doi: 10.1111/j.1751-9004.2007.00001.x

Brandão, H. P., Borges-Andrade, J. E., Puente-Palacios, K., \& Laros, J. A. (2012). Relationships between learning, context and competency: a multilevel study. BAR - Brazilian Administration Review, 9(1), 1-22. doi: https://dx.doi.org/10.1590/ S1807-76922012000100002

Carver, C. S., \& Scheier, M. F. (1982). Control theory: A useful conceptual framework for personality-social, clinical, and health psychology. Personality Bulletin, 92, 111-135. doi: 10.1037/0033-2909.92.1.111

Cieciuch, J., \& Schwartz, S. H. (2012). The number of distinct basic values and their structure assessed by PVQ-40. Journal of Personality Assessment, 94(3), 321-328. doi: 10.1080/00223891.2012.655817

Elliot, A.J., \& Fryer, J. (2008). The goal construct in psychology. In J. Shah \& W. Gardner (Eds.), Handbook of Motivation Science (pp. 235-250). New York, NY: The Guilford Press.

Elster, A. \& Sagiv, L. (2015). Schwartz Value Theory. Wiley Encyclopedia of Management, 6, 1-2. doi: 10.1002/9781118785317.weom060176

Fryer, L., Ginns, P., \& Walker, R. (2014). Between students' instrumental goals and how they learn: Goal content is the gap to mind. British Journal of Educational Psychology, 84(4), 612-630. doi: 10.1111/ bjep. 12052

Gaudreau, P., Carraro, N., \& Miranda, D. (2012). From goal motivation to goal progress: the mediating role of coping in the Self-Concordance Model. Anxiety, Stress \& Coping, 25(5), 507-528. doi: 10.1080/10615806.2011.628015 
Gollwitzer, P. M., \& Moskowitz, G. B. (1996). Goal effects on thought and behavior. In E. T. Higgins \& A. W. Kruglanski (Eds.), Social psychology: Handbook of basicprinciples (pp. 361-399). New York: Guilford Press.

Greenhaus, J. H., Callanan, G. A., \& Godshalk, V. M. (2010). Career management (4th ed.). Thousand Oaks, CA: SAGE Publications, Inc.

Hall, D. T. (1996). Protean careers of the 21st century. Academy of Management Executive, 4, 8-16. doi:10.5465/AME.1996.3145315

Heslin, P. (2005). Conceptualizing and evaluating career success.Journal of Organizational Behaviour, 2, 113136. doi:10.1002/job. 270

Huang, S. C., Zhang, Y., \& Broniarczyk, S. M. (2012). So near and yet so far: The mental representation of goal progress. Journal of Personality and Social Psychology, 103(2), 225-241. doi: 10.1037/a0028443

Hyvönen, K., Feldt, T., Salmela-Aro, K., Kinnunen, U., \& Mäkikangas, A. (2009). Young managers' drive to thrive: A personal work goal approach to burnout and work engagement. Journal of Vocational Behavior, 75, 183-196. doi:10.1016/j.jvb.2009.04.002

Inkson, K., Dries, N., \& Arnold, J. (2015). Understanding careers (2nd Ed.). Thousand Oaks, CA: SAGE Publications, Inc.

Kline, R. B. (2010). Principles and practice of structural equation modeling $\left(3^{\text {rd }}\right.$. ed.). New York: Guilford Press.

Klug, H. J. P., \& Maier, G. W. (2015) Linking goal progress and subjective well-being: A meta-analysis. Journal of Happiness Studies, 16, 37-65. doi: http:// dx.doi.org/10.1007/s10902-013-9493-0

Lambert, L. S., Tepper, B. J., Carr, J. C., Holt, D. T., \& Barelka, A. J. (2012). Forgotten but not gone: an examination of fit between leader consideration and initiating structure needed and received. Journal of Applied Psychology, 97(5), 913-930. doi: 10.1037/ a0028970

Linley, P. A., Nielsen, K. M., Wood, A. M., Gillett, R., \& Biswas-Diener, R. (2010). Using signature strengths in pursuit of goals: Effects on goal progress, need satisfaction, and well-being, and implications for coaching psychologists. International Coaching Psychology Review, 5(1), 8-17. Disponível em: https:// meredithroach.files.wordpress.com/2011/05/ strengths-_goals.pdf. Acessado em: 3 de dezembro de 2017.

Little, B. R., \& Gee, T. L. (2007). The methodology of personal project analysis: Four modules and a funnel. In B. R. Little, K. Salmela-Aro, \& S. D. Phillips (Eds.), Personal project pursuit. Goals, action, and human flourishing (pp. 51-93). Mahwah, NJ: Lawrence Erlbaum Associates.

Locke, E. A., \& Latham, G. P. (2002). Building a practically useful theory of goal setting and task motivation. American Psychologist, 57(9), 705-717. doi: 10.1037/0003-066X.57.9.705

Monzani, D., Steca, P., Greco, A., D’Addario, M., Pancani, L., \& Cappelletti, E. (2015). Effective pursuit of personal goals: The fostering effect of dispositional optimism on goal commitment and goal progress. Personality and Individual Differences, 82, 203-214. doi: 10.1016/j.paid.2015.03.019

Myrseth, K. O. R. \& Fishbach, A. (2009). Self-control: a function of knowing when and how to exercise restraint. Current Directions in Psychological Science, 18, 247-252. doi: 10.1111/j.1467-8721.2009.01645.x

Noe, R. A. (2013). Employee training and development (6th ed.). New York, NY: McGraw Hill.

Nurmi, J. E., Salmela-Aro, K., \& Koivisto, P. (2002). Goal importance and related achievement beliefs and emotions during the transition from vocational school to work: Antecedents and consequences. Journal of Vocational Behavior, 60, 241-261. doi:10.1006/jvbe.2001.1866

Porto, J. B., \& Pilati, R. (2010). Escala revisada de Valores relativos ao Trabalho - EVT-R. Psicologia: Reflexão e Crítica, 23(1), 73-82. doi: https://dx.doi. org/10.1590/S0102-79722010000100010

Schwartz, S. H. (1992). Universals in the content and structure of values: Theoretical advances and empirical tests in 20 countries. In M.P. Zanna (Ed.), Advances in experimental social psychology. Vol. 24 (pp.1-65). San Diego: Academic.

Schwartz, S. H., Cieciuch, J., Vecchione, M., Davidov, E., Fischer, R., Beierlein, C., Ramos, A., Verkasalo, M., Lönnqvist, J. E., Demirutku, K., Dirilen-Gumus, O., \& Konty, M. (2012). Refining the theory of basic individual values. Journal of Personality and Social Psychology,103, 663-688. doi: 10.1037/a0029393. 
Sheldon, K. M., \& Kasser, T. (1998). Pursuing personal goals: Skills enable progress but not all progress is beneficial. Personality and Social Psychology Bulletin, 24, 1319-1331. doi:10.1177/01461672982412006

Sheldon, K. M., \& Elliot, A. J. (1999). Goal striving, need satisfaction, and longitudinal wellbeing: The self-concordance model. Journal of Personality and Social Psychology, 76, 546-557. doi: 10.1037//0022-3514.76.3.482

Smith, A., Ntoumanis, N., Duda, J. L., \& Vansteenkiste, M. (2011). Goal striving, coping, and well-being in sport: A prospective investigation of the selfconcordance model. Journal of Sport and Exercise Psychology, 33, 124-145. doi: 10.1123/jsep.33.1.124

Verstuyf, J., Patrick, H., Vansteenkiste, M., \& Teixeira, P. J. (2012). Motivational dynamics of eating regulation: A self-determination theory perspective. International Journal of Behavioral Nutrition and Physical Activity, 9, 1-16. doi: 10.1186/1479-5868-9-21

Webb, T. L., Chang, B., \& Benn, Y. (2013). The ostrich problem: Motivated avoidance or rejection of information on goal progress. Social and Personality Psychology Compass, 7(11), 794-807. doi: 10.1111/ spc3.12071

Wiese, B. S., \& Salmela-Aro, K. (2008). Goal conflict and facilitation as predictors of work-family satisfaction and engagement. Journal of Vocational Behavior, 73, 490-497. doi: 10.1016/j.jvb.2008.09.007

Recebido em: 20/12/2017 Reformulado em: 05/04/2018

Aprovado em: 17/05/2018

Sobre os autores:

Ligia Carolina Oliveira-Silva, PhD in Social, Work and Organizational Psychology at Universidade de Brasilia and professor of Work and Organizational Psychology at the Institute of Psychology at Universidade Federal de Uberlândia. Head of the Research Group in Career, Professional Fulfillment and Coaching (CNPq).

ORCID: 0000-0002-7487-9420

E-mail: ligiacarol1987@hotmail.com

Juliana Barreiros Porto holds a PhD degree and is a professor at the Department of Social and Work Psychology and at the Graduate Program in Social, Work and Organizational Psychology at Universidade de Brasilia. Head of the Center for Research in Culture, Values and Behavior (CNPq) and coordinator of the Tamayo Group at UnB.

ORCID: 0000-0001-9164-2719

E-mail: porto.juliana@gmail.com

John Arnold is a Professor of Organizational Behavior at the School of Business and Economics at Loughborough University, Leicester, United Kingdom. Member and Honorary Psychologist of the British Psychological Society, author of books such as "Understanding careers" (Sage Publications, 2014) and "Managing careers in the 21st century" (SAGE, 1997).

ORCID: 0000-0002-8623-8057

E-mail:j.arnold@lboro.ac.uk

Contato com os autores:

Instituto de Psicologia/UFU

Av. Pará, no 1720, Umuarama

Uberlândia-MG, Brasil

CEP: 38405-320

Psico-USF, Bragança Paulista, v. 24, n. 1, p. 27-39, jan./mar. 2019 